\title{
AGO2 wt Allele
}

National Cancer Institute

\section{Source}

National Cancer Institute. AGO2 wt Allele. NCI Thesaurus. Code C84490.

Human AGO2 wild-type allele is located in the vicinity of $8 \mathrm{q} 24.3$ and is approximately 122 $\mathrm{kb}$ in length. This allele, which encodes protein argonaute-2, is involved in RNA catabolism and gene silencing. 